\title{
大型商用車用油圧パワーステアリングのモデリングに関する研究*
}

\author{
高 炳 釗 $^{* *}$, 眞 田一志***, 降 幡 健 一 ***
}

\section{A Study on Modeling Hydraulic-Power-Steering for Heavy Duty Vehicles}

\author{
Bingzhao GAO, Kazushi SANADA, Kenichi FURIHATA
}

\begin{abstract}
Hydraulic power steering systems, which can provide a large steering assist force, are widely used for heavy-duty commercial vehicles. For the research of a stability control system for commercial vehicles, a combined simulation model for the vehicle, including IPS (Integral Power Steering) system and vehicle body, was constructed. Then linearization and order-reduction of the simulation model were performed for model based controller design. Compared with experimental results, it was found that the established simulation model can adequately represent the dynamic behavior of the vehicle. The linear low-order model was also verified by comparison of eigenvalues and frequency domain responses. Finally, a yaw rate control system was designed based on the linear models and tested on the combined simulation model, which shows the validity of the simulation model and linearized low-order model.
\end{abstract}

Key words : Hydraulic power steering, Transportation equipment, Heavy duty vehicle, Modeling

\section{1. 緒言}

大型商用車はさまざまな用途で用いられているが, 近年 快適性と操縦安定性が強く求められており, 制御性, 安定 性, 安全性に関する研究1) が盛んに行われている. 操舵力 をアシストする装置として油圧式および電気式のパワー ステアリングがあるが, 大型商用車では出力の大きな油圧 式パワーステアリングが用いられている，本研究は, 大型 商用車のハンドル操作を含めた車両の操縦安定性の改良 を目的としており，本論文では特に油圧式パワーステアリ ングモデルの構築とその制御系設計への適用手法につい て検討した. 油圧式パワーステアリングとして大型商用車 に多く用いられている，インテグラル型パワーステアリン グ $(\mathrm{IPS})^{2)}$ を対象とした.

油圧式パワーステアリングに関する研究は従来から盛 んに行われており，たとえば小嶋ら ${ }^{3)}$ は油圧式パワーステ アリングシステムに発生する自励振動現象を理論および 実験により解析し, その発生メカニズムとパラメータが安

\footnotetext{
*平成19年 6 月 29 日 原稿受付

**横浜国立大学大学院工学府

(所在地 ₹240-8501 横浜市保土ヶ谷区常盤台79-5) 吉林大学汽車工程学院

$* * *$ 横浜国立大学大学院工学研究院

(所在地 テ240-8501 横浜市保土ヶ谷区常盤台79-5)

(E-mail: ksanada@ynu.ac.jp)

****株式会社 いすぐ中央研究所車両研究第二部

(所在地 $\bar{\top} 252-0806$ 神奈川県藤沢市土棚 8)
}

定性に及ぼす影響を把握するシミュレーション技術を明 らかにした. 一方, Pfefferら ${ }^{4)}$ は, 油圧式パワーステアリ ングにおけるハンドルトルクの推定を目的として, 摩擦特 性を考慮したモデリングに関する研究を行っている.ま た, Baharomら ${ }^{5)}$ は, 乗用車がコーナリングする祭の運動 性能の検討を目的として, 油圧式パワーステアリングと車 両運動のモデルを統合したモデルについて検討した.

乗用車の操舵制御の研究例として, 近年, 人間-自動車 系の制御性, 安定性, 安全性を改善するために, 左右制動 力配分とアクティブフロントステアリングシステムによ り制御するシステムが検討されている ${ }^{6)}$.7). それらのシス テムはドライバーの希望の挙動を計算する一方, 予定の コースから外れる傾向をも検知する. ドリフトアウトやス ピンなど危険な事態を回避することにより, 車両の安定性 を確保する. ヨーレート制御はその方法の一種である ${ }^{8), 9)}$. これらの研究成果から貴重な知見が得られているが, 本 論文の目的である油圧式パワーステアリングを搭載した 大型商用車におけるモデル構築と制御系設計への適用手 法に関する研究は見あたらない. 油圧パワーステアリング は大型商用車において現在広く用いられており, 油圧パ ワーステアリングの特性を考慮したモデリングおよび操 舵制御系設計の手法を理論的に確立することは, 油圧パ ワーステアリングが今後も広く利用されていく上で非常 に重要なことと考える，そこで本研究では，はじめにIPS と車両運動の統合モデルを導出し, 次にこれを代表的な操 舵制御であるヨーレート制御系の設計に用いる手法につ いて検討した. 特に, ドライバーと車両との相互作用デバ 
イスとして使用されている油圧式反力発生機構を組み込 んだ操舵系について検討した.

第 2 章では，IPSのモデリングと車両運動モデル，およ び統合モデルを導出する．第 3 章では，統合モデルから制 御系設計用の状態方程式モデルを導出する．第 4 章では, ヨーレート制御系設計への適用手法について検討し，その 効果をシミュレーションにより検証する．第 5 章で本研究 の成果をまとめる.

\section{主な 記 号}

\begin{tabular}{|c|c|}
\hline$a_{r v}$ & : 反力制御弁パラメータ \\
\hline$A$ & : ロータリバルブ開口面積 \\
\hline$A_{p}$ & : ボールナット有効受圧面積 \\
\hline$c$ & : 流量係数 \\
\hline$C_{c}$ & : セクタシャフトの等価粘性抵抗係数 \\
\hline$C_{h}$ & : ハンドルシャフト回りの等価粘性抵抗係数 \\
\hline$C_{w s}$ & $\begin{array}{l}\text { : IPSを車両に装着した状態でのウォームシャフ } \\
\text { ト回りの等価粘性抵抗係数 }\end{array}$ \\
\hline$C_{w t}$ & $\begin{array}{l}\text { : IPS単体の状態でのウォームシャフト回りの等 } \\
\text { 価粘性抵抗係数 }\end{array}$ \\
\hline$d_{f}$ & : 車両トレッド \\
\hline$g_{m 2}$ & : バルブ流量特性線形近似パラメータ \\
\hline$i$ & : 反力制御弁駆動電流 \\
\hline$I_{h}$ & : ハンドルシャフト回りの慣性モーメント \\
\hline$I_{w s}$ & $\begin{array}{l}\text { : IPSを車両に装着した状態でのウォームシャフ } \\
\text { ト回りの等価慣性モーメント }\end{array}$ \\
\hline$I_{w t}$ & $\begin{array}{l}\text { : IPS単体の状態でのウォームシャフト回りの等 } \\
\text { 価慣性モーメント }\end{array}$ \\
\hline$I_{z}$ & : 車両Z軸回りの慣性モーメント \\
\hline$K$ & : 作動油の体積弾性係数 \\
\hline$K_{c}$ & : セクタシャフトの等価ばね定数 \\
\hline$K_{c t}$ & : ウォームシャフト回りの等価負荷ばね定数 \\
\hline$K_{f}, K_{r}$ & : 前後輪のコーナリングパワー \\
\hline$K_{r v}$ & : 反力制御弁比例係数 \\
\hline$K_{s}$ & : 左右輪すべり率の差と制動力の比例係数 \\
\hline$K_{t}$ & : トーションバーのばね定数 \\
\hline$l_{f}, \quad l_{r}$ & : 車両重心点と前後車軸間の距離 \\
\hline$m$ & : 車両質量 \\
\hline$n$ & : ウォームシャフトから車輪までの伝達比 \\
\hline$p_{a}, p_{b}$ & : シリンダ室の圧力 \\
\hline$p_{l}$ & : シリンダ負荷圧力 \\
\hline$p_{r e}$ & : 反力室圧力 \\
\hline$p_{s}$ & : 供給圧力 \\
\hline$p_{t}$ & : タンク圧力 \\
\hline$Q_{1}$ & : シリンダ室aからタンクへの流量 \\
\hline$Q_{2}$ & : 高圧配管からシリンダ室aへの流量 \\
\hline$Q_{3}$ & : 高圧配管からシリンダ室bへの流量 \\
\hline
\end{tabular}

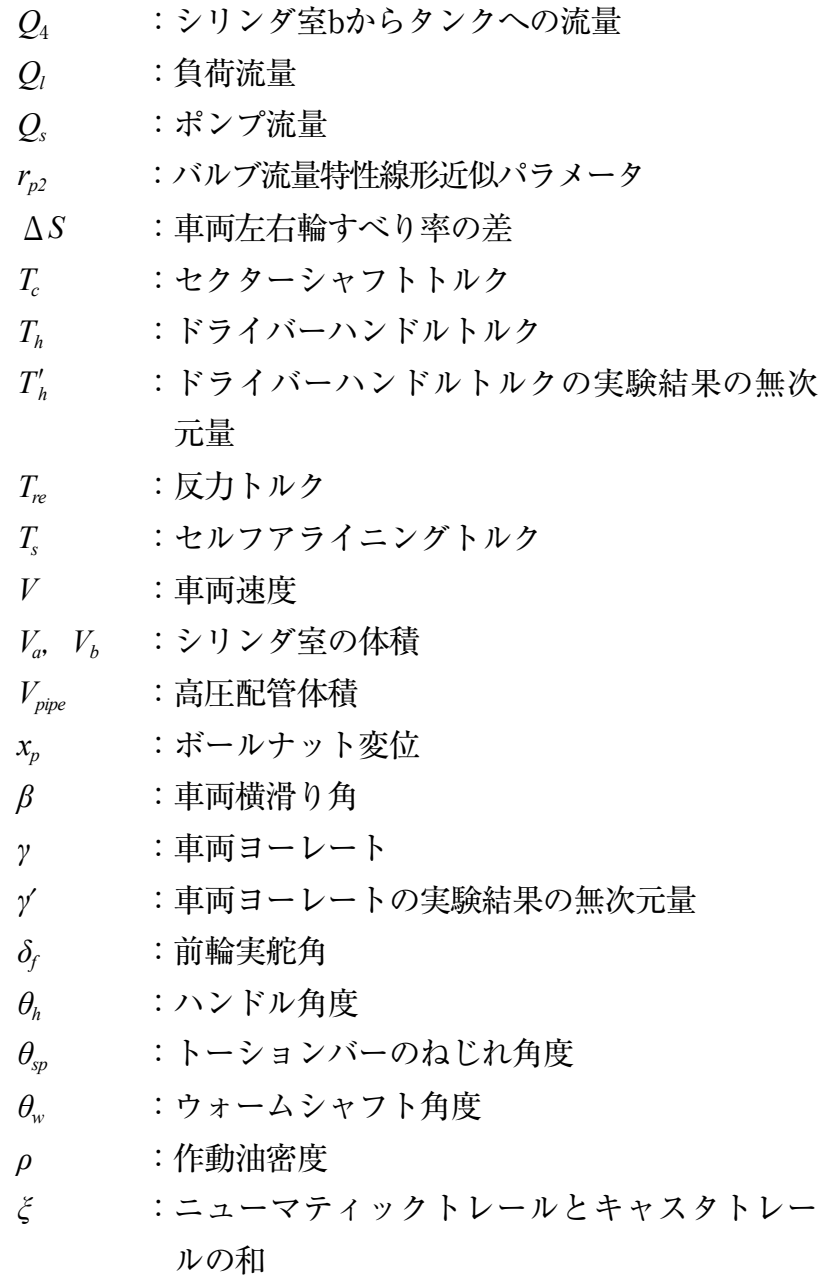

\section{2. 統合モデルの導出}

\section{1 油圧式パワーステアリング}

IPS型パワーステアリングの構成をFig. 1 に示す ${ }^{2}$. 図に 示すように, システムは, パワーステアリングギア, ロー タリバルブ，オイルポンプ，オイルタンク，配管などを主 要部品として構成されている. ハンドルはロータリバルブ のスプールにつながり，スプールとスリーブの間にトー

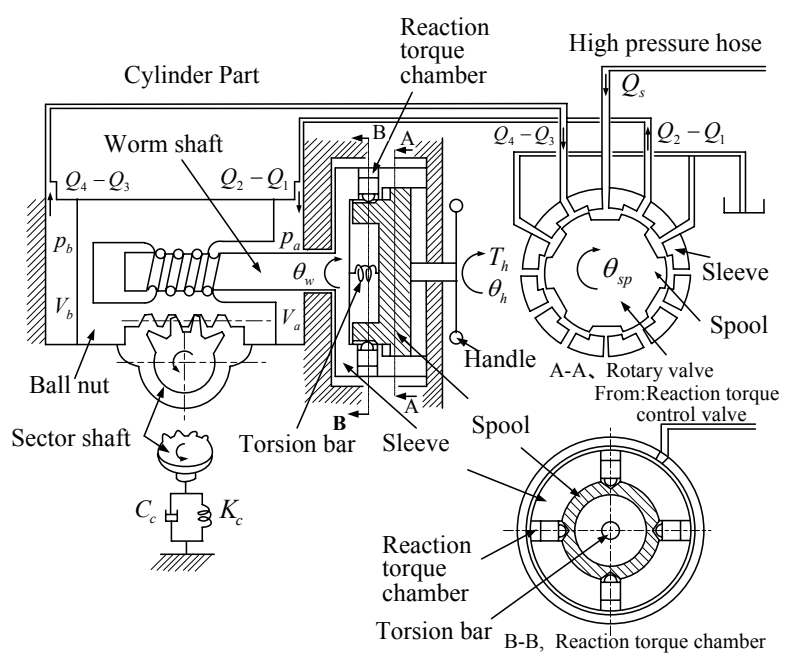

Fig. 1 Schematic diagram of IPS 
ションバーが設けられている. ハンドルトルク $T_{h}$ が作用す ると, トーションバーのねじれ角度 $\theta_{s p}$ が増加し, 高圧配管 とシリンダ室aの間の絞りの開口面積およびシリンダ室b とタンクの間の絞りの開口面積が増加し, シリンダ室aと bの差圧が大きくなる. 差圧によって生じる力はボール ナットを介してセクタシャフトに伝わり, 操舵力をアシス トする.ささらに, 本論文では, ハンドルに反カトルクを発 生させるために, ロータリバルブのスプール部に従来から 用いられている反カトルク機構を追加している. はじめ に, これらのモデリングについて述べる10),11),12).

(a) ポンプ

ポンプ吐出流量は $Q_{s}$ とする.

(b) 高圧配管

高圧配管内の作動油の圧縮性をモデル化する。この場 合, ポンプ吐出圧力とコントロールバルブ供給圧力は等し くなり, 高圧配管の流量収支により圧力が時間変化する. すなわち, 次式となる.

$$
\frac{d p_{s}}{d t}=\frac{K}{V_{\text {pipe }}}\left(Q_{s}-Q_{2}-Q_{3}\right)
$$

(c) コントロールバルブ

コントロールバルブはロータリ形であり，正味のねじれ 角度 $\theta_{s p}$ は次式のようになる。

$$
\theta_{s p}=\theta_{h}-\theta_{w}
$$

コントロールバルブは， 4 ポート 3 位置オープンセンタ 型バルブを円周状に三つ設けた絞りからなるブリッジ回 路であり，それぞれの絞りの開口面積はねじれ角度 $\theta_{s p}$ の関 数として変化する．4つの絞りの流量は，それぞれ以下の 式で表される.

$$
\begin{aligned}
& Q_{1}=c A\left(\theta_{s p}\right) \sqrt{\frac{2\left|p_{a}-p_{t}\right|}{\rho}} \operatorname{sgn}\left(p_{a}-p_{t}\right) \\
& Q_{2}=c A\left(-\theta_{s p}\right) \sqrt{\frac{2\left|p_{s}-p_{a}\right|}{\rho}} \operatorname{sgn}\left(p_{s}-p_{a}\right) \\
& Q_{3}=c A\left(\theta_{s p}\right) \sqrt{\frac{2\left|p_{s}-p_{b}\right|}{\rho}} \operatorname{sgn}\left(p_{s}-p_{b}\right) \\
& Q_{4}=c A\left(-\theta_{s p}\right) \sqrt{\frac{2\left|p_{b}-p_{t}\right|}{\rho}} \operatorname{sgn}\left(p_{b}-p_{t}\right)
\end{aligned}
$$

（d） 反力室と反力制御弁

油圧式反力機構はFig. 1 に示すように，ロータリバルブ 部に設置される．スプール部に加えるピストンの推力か ら, 戻りトルクが得られる. 反力トルク微小变動 $\Delta T_{r e}$ は反 力室圧力微小変動 $\Delta p_{r e}$ に比例すると仮定する.

$$
\Delta T_{r e}=K_{r e} \Delta p_{r e}
$$

反力トルク機構は一般に復帰トルクを発生するもので あり, ピストンが左右斜面のどちらに着くかはトーション

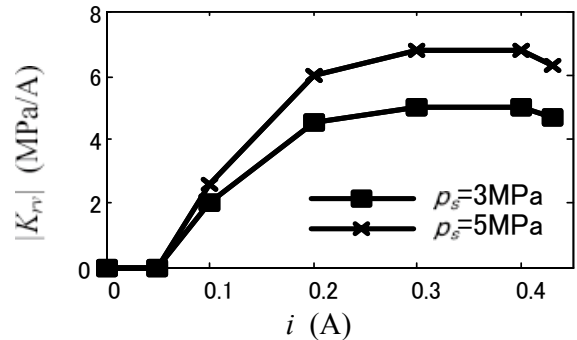

(a) $\left|K_{r v}\right|$

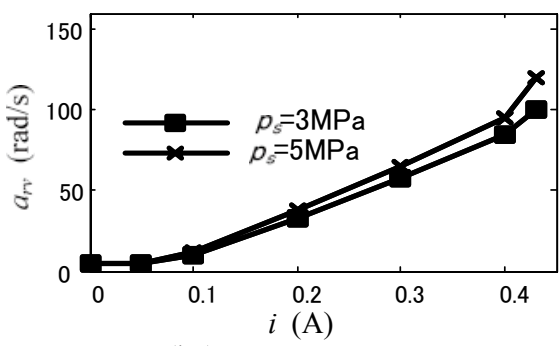

(b1) $a_{r v}$ : output pressure steps up

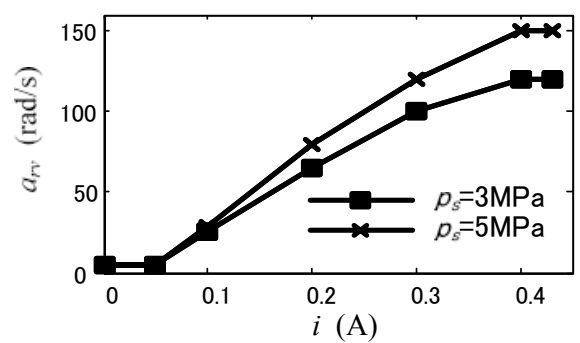

(b2) $a_{r v}$ : output pressure steps down

Fig. 2 Parameters variation of reaction torque control valve

バーのねじれ角度 $\theta_{s p} に よ り$ 定まる. すなわち, 比例係数 $K_{r e}$ の符号は以下の式で表される.

$$
K_{r e} \begin{cases}\geq 0 & \theta_{s p} \geq 0 \\ <0 & \theta_{s p}<0\end{cases}
$$

また, 反力室圧力は反力室につながる反力制御弁で制御 される. 反力室圧力 $\Delta p_{r e}$ の駆動電流 $\Delta i$ に対する動特性を 1 次遅れで近似し，実験データをもとに同定した。

$$
\frac{d}{d t} \Delta p_{r e}=-a_{r v} \Delta p_{r e}+K_{r v} a_{r v} \Delta i
$$

実機応答を局所的に近似するために，パラメータ $a_{r v}$ と $K_{v v}$ は固定せず, ルックアップテーブルによって供給圧力 $p_{s}$ と入力電流iによって值をとるようにした。 ルックアップ テーブルのデータをFig. 2 に表す． $K_{r v}$ は絶対值として表し， $a_{r v}$ は出力圧力 $p_{r e}$ が増加する場合 (Fig. 2 (b1)) と減少す る場合（Fig. 2 （b2））によって場合分けした.

(e) シリンダ室内の作動油の圧縮性

シリンダ室内の作動油の圧縮性を考慮すると次式が成 り立つ。

$$
\begin{aligned}
& \frac{d p_{a}}{d t}=\frac{K}{V_{a 0}+A_{p} x_{p}}\left(Q_{a}-A_{p} \frac{d x_{p}}{d t}\right) \\
& \frac{d p_{b}}{d t}=\frac{K}{V_{b 0}-A_{p} x_{p}}\left(A_{p} \frac{d x_{p}}{d t}-Q_{b}\right)
\end{aligned}
$$


（f） 伝達部の回転の運動方程式

ハンドルからセクタシャフトまでの伝達部の回転の運 動方程式は以下の二つの式で表される.

$$
\begin{aligned}
I_{h} \frac{d^{2} \theta_{h}}{d t^{2}} & =T_{h}-K_{t} \theta_{s p}-C_{h} \frac{d \theta_{h}}{d t}-T_{r e} \\
I_{w t} \frac{d^{2} \theta_{w}}{d t^{2}} & =K_{t} \theta_{s p}-C_{w t} \frac{d \theta_{w}}{d t}-K_{c t} \theta_{w} \\
& +A_{p t}\left(p_{a}-p_{b}\right)+T_{r e}
\end{aligned}
$$

車両モデルと統合する前に, IPS単体の特性をシミュ レーションで検討する. シミュレーションに用いた主な諸 元をTable 1 に示す. セクタシャフトの等価ばね定数 $K_{c}$ は, IPSの出力に関する主要なパラメータである. 実機では,
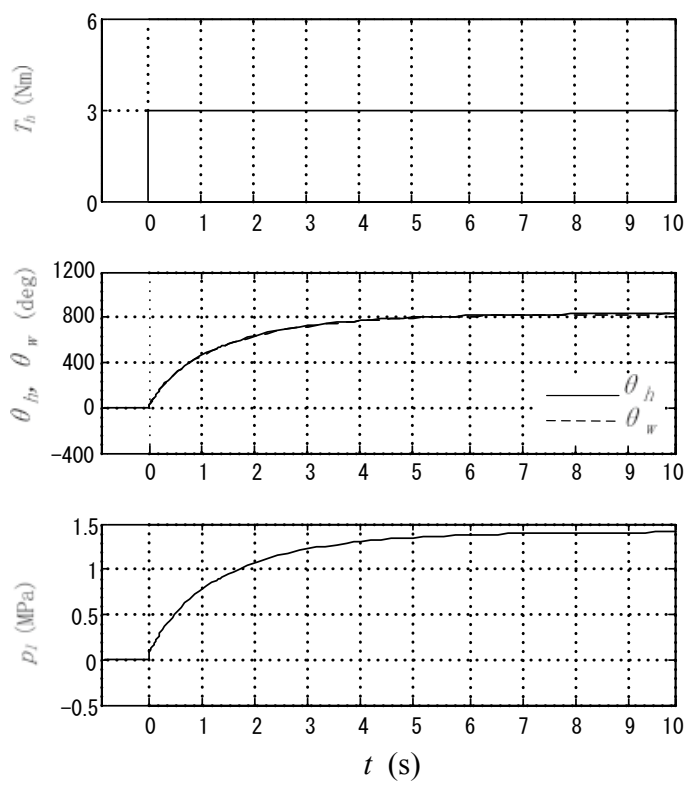

Fig. 3 Step responses of IPS
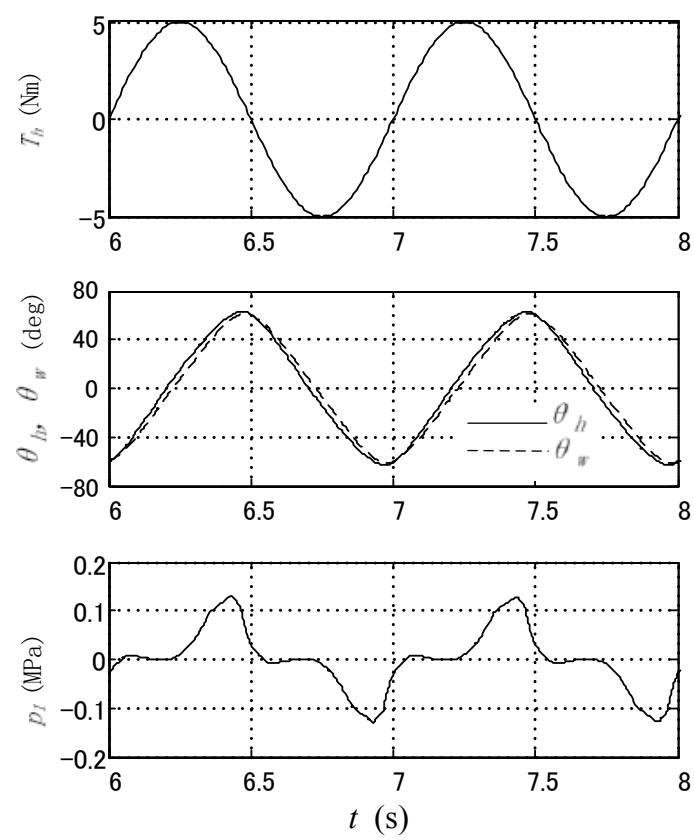

Fig. 4 Simulation results of IPS (the frequency of $T_{h}$ : $1 \mathrm{~Hz}$, amplitude : $\pm 5 \mathrm{Nm}$ )

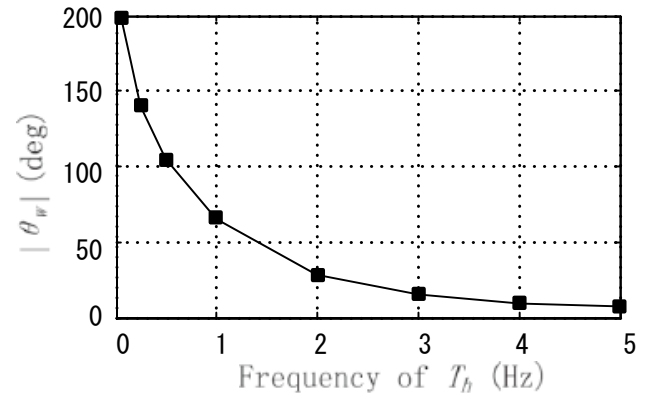

Fig. 5 Angle amplitude response to handle torque of different frequencies (amplitude : $\pm 5 \mathrm{Nm}$ )

Table 1 Main parameters for IPS simulation

\begin{tabular}{|l|l|}
\hline$K$ & $0.8 \mathrm{GPa}$ \\
\hline$K_{c}$ & $3000 \mathrm{Nm} / \mathrm{rad}$ \\
\hline$Q_{s}$ & $18 \mathrm{~L} / \mathrm{min}$ \\
\hline$\rho$ & $860 \mathrm{~kg} / \mathrm{m}^{3}$ \\
\hline
\end{tabular}

セクタシャフトからタイヤまでの機構部およびタイヤ特 性を含めた剛性が関与するが，ここではIPS単体のシミュ レーションを行うことが目的であり, それらの剛性を等価 的に表すパラメータとして $K_{c}$ を用いた.

ハンドルトルク $T_{h}$ を時刻0sで 0 から $3 \mathrm{Nm}$ にステップ状 に変化させた場合の結果をFig. 3 に示す. ハンドルトルク に対して, ハンドル角度 $\theta_{h}$ とウォームシャフト角度 $\theta_{w}$, シ リンダの負荷圧力 $p_{l}$ の応答を示す．ハンドルトルク $T_{h}$ のス テップ変化に対して, ハンドル角度 $\theta_{h}$ 及び負荷圧力 $p_{l}$ が増 加する.これらのステップ応答を 1 次遅れとみなせば, そ の時定数は, 約 $1.5 \mathrm{~s}$ であることがわかる.

ハンドルトルク $T_{h}$ が周期的に変動する場合の応答を求め た. 操舵力が周波数 $1 \mathrm{~Hz}$ の場合の計算結果をFig. 4 に示す. IPS単体の周波数応答として, 異なる周波数のハンドルトル クを加えたときの操舵角度の振幅をFig. 5 に示す. 周波数 の増加とともに, 角度振幅は大幅に減衰することがわかる.

\section{2 車両運動モデル}

一定速度で走行している車両の水平面内の運動を考え

る. Fig. 6 に示すように, 車両の車輪幅を無視し, 左右輪

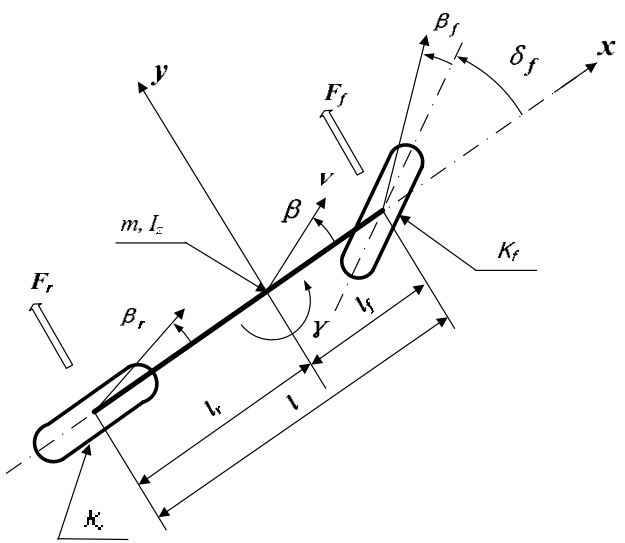

Fig. 6 Two-wheel vehicle model 
が車両の前後軸と車軸との交点にそれぞれ集中している 車両の運動を考える．このように，車体に固定された座標 系における車両の運動方程式は，剛体運動である重心点の 横滑りの運動方程式（式14）と車体の重心点回りの回転の 運動方程式（式15）でその運動が表され，これは車両の 2 輪モデル ${ }^{14), 15)}$ と呼ばれている.

$$
\begin{aligned}
\frac{d \beta}{d t} & =-\frac{1}{m V}\left(K_{f}+K_{r}\right) \beta \\
& -\left\{1+\frac{1}{m V^{2}}\left(l_{f} K_{f}-l_{r} K_{r}\right)\right\} \gamma+\frac{K_{f}}{m V} \delta_{f} \\
\frac{d \gamma}{d t} & =-\frac{1}{I_{z}}\left(l_{f} K_{f}-l_{r} K_{r}\right) \beta-\frac{1}{I_{z} V}\left(l_{f}^{2} K_{f}+l_{r}^{2} K_{r}\right) \gamma \\
& +\frac{l_{f} K_{f}}{I_{z}} \delta_{f}+\frac{d_{f} K_{s}}{2 I_{z}} \Delta S
\end{aligned}
$$

ただし，式(15)の右辺第 4 項で, 左右の夕イヤの滑り率の 差 $\Delta S$ による旋回モーメントの影響を加えている.

車両のモデルは前輪からハンドルまで伝わるセルフア ライニングトルク $T_{s}$ を通して, IPS部分と相互に関連づけ られる. すなわち, 式(13)の中のウォームシャフト回りの等 価慣性モーメント $I_{w t}$ と粘性抵抗係数 $C_{w t}$ を, IPSが車両に装 着された場合の等価慣性モーメント $I_{w s}$ と粘性抵抗係数 $C_{w s}$ に変え, 負荷トルクをセルフアライニングトルク $T_{s}$ に変更 する.さらに, 式(14), 式(15)の $\delta_{f}$ は $(1 / n) \theta_{w}$ に等しいので, 式(13)〜(15)は次の式になる.

$$
\begin{aligned}
& I_{w s} \frac{d^{2} \theta_{w}}{d t^{2}}=K_{t} \theta_{s p}-C_{w s} \frac{d \theta_{w}}{d t}+\frac{1}{n} T_{s} \\
& +A_{p t}\left(p_{a}-p_{b}\right)+T_{r e} \\
& \frac{d \beta}{d t}=-\frac{1}{m V}\left(K_{f}+K_{r}\right) \beta \\
& -\left\{1+\frac{1}{m V^{2}}\left(l_{f} K_{f}-l_{r} K_{r}\right)\right\} \gamma+\frac{K_{f}}{n m V} \theta_{w} \\
& \frac{d \gamma}{d t}=-\frac{1}{I_{z}}\left(l_{f} K_{f}-l_{r} K_{r}\right) \beta-\frac{1}{I_{z} V}\left(l_{f}^{2} K_{f}-l_{r}^{2} K_{r}\right) \gamma \\
& +\frac{l_{f} K_{f}}{n I_{z}} \theta_{w}+\frac{d_{f} K_{s}}{2 I_{z}} \Delta S
\end{aligned}
$$

ただし，

$$
T_{s}=\xi K_{f} \beta_{f}=\xi K_{f}\left(\beta+\frac{l_{f}}{V} \gamma-\delta_{f}\right)
$$

本論文で対象とする大型商用車の諸元をTable 2 に示す.

Table 2 Main parameters of vehicle

\begin{tabular}{|l|l|}
\hline$d_{f}$ & $2.0 \mathrm{~m}$ \\
\hline$I_{z}$ & $2 \times 10^{5} \mathrm{kgm}^{2}$ \\
\hline$K_{f}$ & $250000 \mathrm{~N} / \mathrm{rad}$ \\
\hline$K_{r}$ & $460000 \mathrm{~N} / \mathrm{rad}$ \\
\hline$l_{f}$ & $4.0 \mathrm{~m}$ \\
\hline$l_{r}$ & $2.5 \mathrm{~m}$ \\
\hline$m$ & $22000 \mathrm{~kg}$ \\
\hline
\end{tabular}
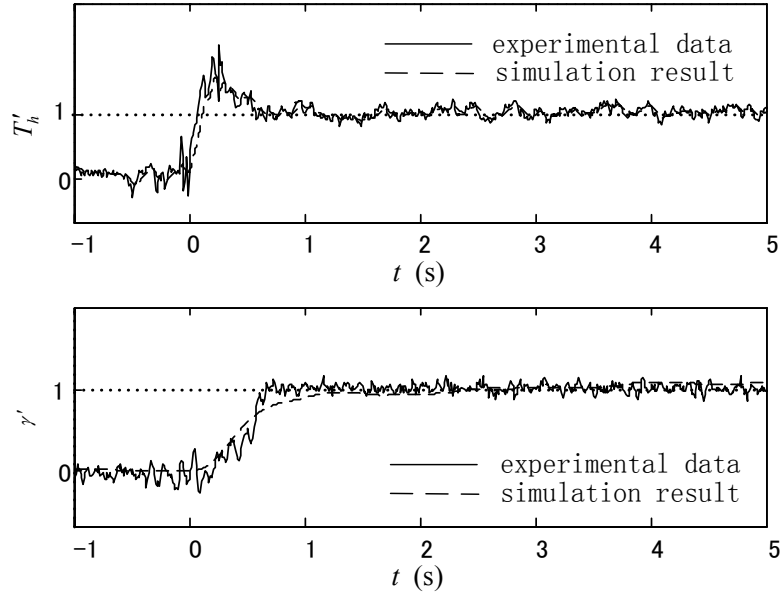

Fig. 7 Comparison of yaw rate when handle angle step to $90 \mathrm{deg}$
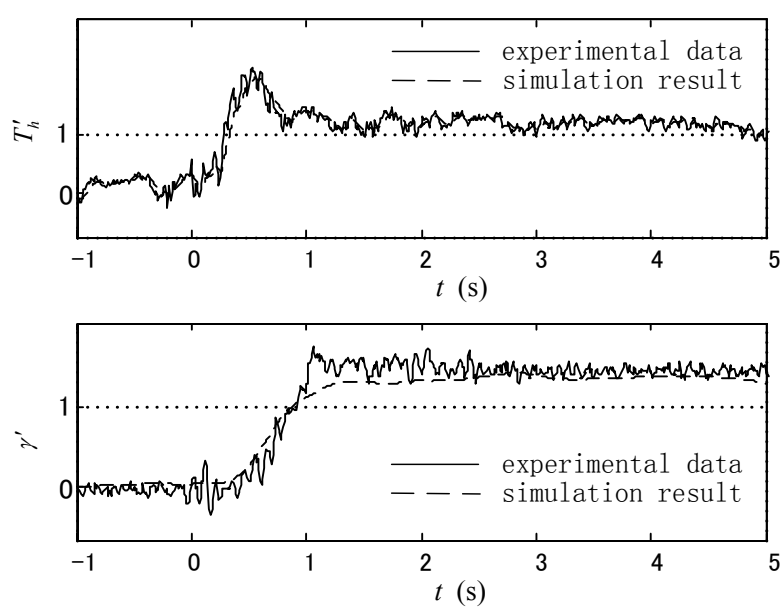

Fig. 8 Comparison of yaw rate when handle angle step to $120 \mathrm{deg}$

\section{3 統合モデルの検証}

IPSモデルと車両モデルを組み合わせることによって統 合モデルが構築される. 本研究では操舵反力を制御入力と して扱うので, ハンドルトルクを操舵入力としたシステム の応答について，実験結果と統合モデルのシミュレーショ ン結果を比較し, 統合モデルの有効性について検討する.

車速は $40 \mathrm{~km} / \mathrm{h}$ 保持するものとし，ハンドル角を $0 \mathrm{deg}$ から90degまたは120degまで0.5s程度でテストドライバが 操舵する実験を行った. その結果, 定常状態のハンドルト ルクは $3 \mathrm{Nm}$ と $3.3 \mathrm{Nm}$ だけ変化した. ハンドルトルク $T_{h}{ }^{\prime}$ と 車両ヨーレート $\gamma^{\prime}$ の結果をFig. 7 とFig. 8 に実線で示す. これらの結果を表示する際にはハンドル角 $\theta_{h}$ が $90 \mathrm{deg}$ の場 合の結果を基準の 1 としている. シミュレーションでは, ハンドルトルク $T_{h}^{\prime}$ の実験結果をローパスフィルタ（カッ トオフ周波数 : $50 \mathrm{~Hz}$ ）に通した結果を入力とした. フィ ルタを経たハンドルトルク $T_{h}{ }^{\prime}$ とヨーレート $\gamma^{\prime}$ のミミュ レーション結果を破線で表す。ヨーレートのシミュレー ション結果と実験結果がよく一致することから, 本統合モ デルの有効性が示された. 


\section{3. 運動制御系設計用モデルの構築}

\section{1 線形近似モデルの導出}

ここまでは，実機特性をよく再現するために，ロータリ バルブの非線形流量特性と反力制御弁パラメータの変動 などを考慮し，IPSを車両と統合した非線形シミュレー ションモデルを構築した． 線形制御理論を適用するため に，ここでは非線形モデルの線形化を行う.

ロータリバルブの負荷流量の微小変動 $\Delta Q_{1}$ は, ねじれ角 度の微小変動 $\Delta \theta_{s p}$ と負荷圧力の微小変動 $\Delta p_{l}$ により次式の ように線形近似される。

$$
\Delta Q_{l}=g_{m 2} \Delta \theta_{s p}-\frac{1}{r_{p 2}} \Delta p_{l}
$$

パワーシリンダの負荷圧力は, シリンダ室の作動油の圧 縮性から次式によって求められる.

$$
\frac{d \Delta p_{l}}{d t}=K_{v}\left(\Delta Q_{l}-A_{p t} \frac{d \Delta \theta_{w}}{d t}\right)
$$

また，反力制御弁のパラメータである $K_{r v}$ と $a_{r v}$ は，比較 的使用頻度が高いと考えられる動作領域を設定し，その領 域における同定結果を用いた， $K_{r v}$ は，供給圧力 $p_{s}$ が $2 \sim 3$ $\mathrm{MPa}$ の領域における同定結果である值－5 $\mathrm{MPa} / \mathrm{A}$ とした。

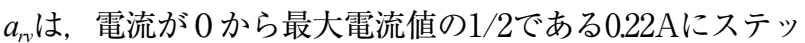
プ状に増加する場合の応答から同定された值である40rad/ 心に設定した。

以上の基礎式から状態方程式が求まる.

$$
\frac{d}{d t} x=A x+B u+E T_{h}
$$

状態変数は次式で表される.

$$
x=\left[\begin{array}{lllllll}
\theta_{h} \dot{\theta}_{h} & \theta_{w} & \dot{\theta}_{w} & p_{l} & p_{r e} & \beta & \gamma
\end{array}\right]^{T}
$$

また，制御入力は反力制御弁駆動電流 $\Delta i$ と左右輪のス リップ率の差 $\Delta S$ である.

$$
u=[\Delta i \Delta S]^{T}
$$

係数行列 $A, B, E$ は,

$$
\begin{aligned}
A & =\left[\begin{array}{cccccccc}
0 & 1 & 0 & 0 & 0 & 0 & 0 & 0 \\
-\frac{K_{t}}{I_{h}} & -\frac{C_{h}}{I_{h}} & \frac{K_{t}}{I_{h}} & 0 & 0 & -\frac{K_{r e}}{I_{h}} & 0 & 0 \\
0 & 0 & 0 & 1 & 0 & 0 & 0 & 0 \\
\frac{K_{t}}{I_{w s}} & 0 & a_{33} & -\frac{C_{w s}}{I_{w s}} & \frac{A_{p t}}{I_{w s}} & \frac{K_{r e}}{I_{w s}} & \frac{\xi K_{f}}{n I_{w s}} & \frac{\xi K_{f} l_{f}}{n V I_{w s}} \\
K_{v} g_{m 2} & 0 & -K_{v} g_{m 2} & -K_{v} A_{p t} & -\frac{K_{v}}{r_{p 2}} & 0 & 0 & 0 \\
0 & 0 & 0 & 0 & 0 & -a_{r v} & 0 & 0 \\
0 & 0 & \frac{K_{f}}{n m V} & 0 & 0 & 0 & a_{77} & a_{78} \\
0 & 0 & \frac{l_{f} K_{f}}{n I_{z}} & 0 & 0 & 0 & a_{87} & a_{88}
\end{array}\right] \\
B & =\left[\begin{array}{ccccccccc}
0 & 0 & 0 & 0 & 0 & K_{r v} a_{r v} & 0 & 0 \\
0 & 0 & 0 & 0 & 0 & 0 & 0 & \frac{d_{f} K_{s}}{2 I_{z}}
\end{array}\right]^{T} \\
E & =\left[\begin{array}{lllllll}
0 & \frac{1}{I_{h}} & 0 & 0 & 0 & 0 & 0
\end{array}\right]^{T}
\end{aligned}
$$

Table 3 Eigen values of vehicle models

\begin{tabular}{llll}
\hline Full model & $\begin{array}{l}\text { Reduced order } \\
\text { modelt }(1)\end{array}$ & $\begin{array}{l}\text { Reduced order } \\
\text { modelu }(2)\end{array}$ & $\begin{array}{l}\text { Reduced order } \\
\text { modelv }(3)\end{array}$ \\
\hline$-466+201 \mathrm{i}$ & $-368+246 \mathrm{i}$ & -462 & -0.330 \\
$-466-201 \mathrm{i}$ & $-368-246 \mathrm{i}$ & -0.330 & $-5.48+6.25 \mathrm{i}$ \\
$-10.4+106 \mathrm{i}$ & -0.211 & $-5.48+6.25 \mathrm{i}$ & $-5.48-6.25 \mathrm{i}$ \\
$-10.4-106 \mathrm{i}$ & $-5.49+6.28 \mathrm{i}$ & $-5.48-6.25 \mathrm{i}$ & \\
-0.208 & $-5.49-6.28 \mathrm{i}$ & & \\
$-5.47+6.30 \mathrm{i}$ & & & \\
$-5.47-6.30 \mathrm{i}$ & & & \\
-40 & & & \\
\hline
\end{tabular}

である.ただし，

$$
\begin{aligned}
& a_{33}=-\frac{K_{t}+\xi K_{f} / n^{2}}{I_{w s}}, a_{77}=-\frac{K_{f}+K_{r}}{m V}, a_{87}=-\frac{l_{f} K_{f}-l_{r} K_{r}}{I_{z}}, \\
& a_{78}=-\left\{1+\frac{l_{f} K_{f}-l_{r} K_{r}}{m V^{2}}\right\}, a_{88}=-\frac{l_{f}^{2} K_{f}+l_{r}^{2} K_{r}}{I_{z} V}
\end{aligned}
$$

\section{2 モデルの低次元化}

前述の線形近似モデルの次数が 8 次と高いので, 油圧操 舵系の動特性などを考慮して, 以下の 3 種類の低次元モデ ルを導出した.

（1）圧縮性，ハンドル慣性，反力バルブ動特性を省略した 低次元モデル

(2)（1)に加えて，ハンドルの粘性抵抗も省略した低次元モ デル

（3）（2）に加えて，ウォームシャフトの慣性を省略した低次 元モデル

これらのモデルの固有值をTable 3 に示す．太字の固有 值が代表根であり, 低次元化を行っても, 代表根の大きさ に大幅な変化はみられない. また, もとの 8 次モデルと低 次元化した 3 次モデルの, ハンドルトルクから車両ヨー

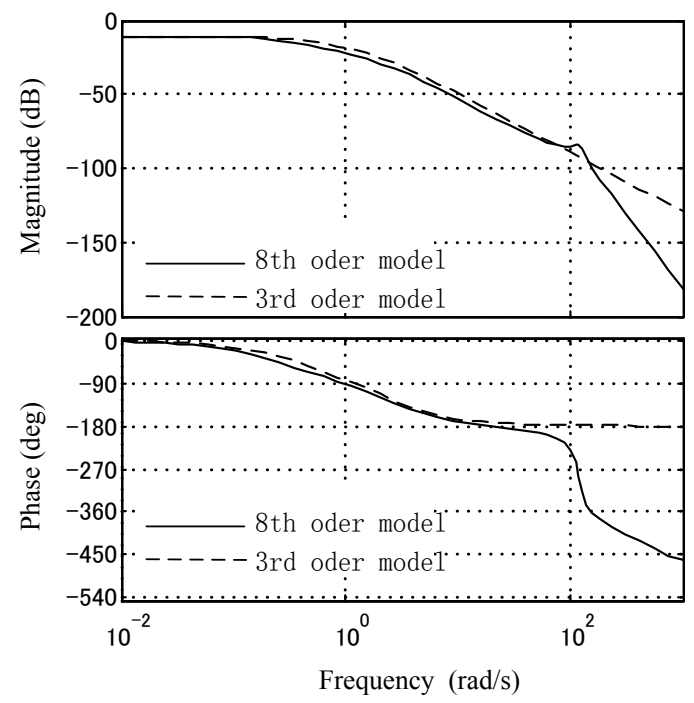

Fig. 9 Comparison of frequency domain responses of 8th order and 3rd order linear model 
レートまでの伝達関数のボード線図をFig. 9 に示す. 100 $\mathrm{rad} / \mathrm{s}$ までの周波数範囲で, 3 次モデルは 8 次モデルと比 べ大きな差異はなく, 低次元モデルの有効範囲は約 100rad/sであることが確認できる.

そこで, 次数の最も低い低次元モデルの状態変数は

$$
x=\left[\begin{array}{lll}
\theta_{w} & \beta & r
\end{array}\right]^{T}
$$

であり，係数行列 $A ， B, E$ は次式で表される.

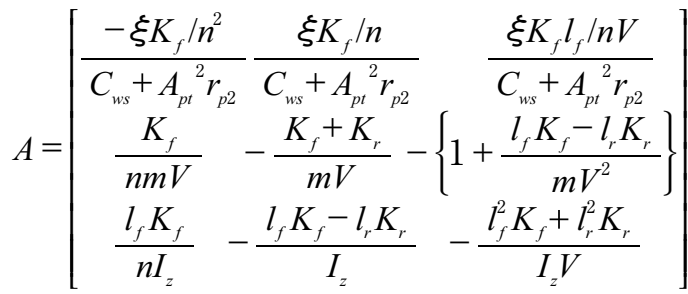

$$
\begin{aligned}
& B=\left[\begin{array}{cc}
-\frac{A_{p t} g_{m 2} r_{p 2} K_{r e} K_{r v} / K_{t}}{C_{w s}+A_{p t}{ }^{2} r_{p 2}} & 0 \\
0 & 0 \\
0 & \frac{d_{f} K_{s}}{2 I_{z}}
\end{array}\right] \\
& E=\left[\begin{array}{c}
\frac{1+A_{p t} g_{m 2} r_{p 2} / K_{t}}{C_{w s}+A_{p t}{ }^{2} r_{p 2}} \\
0 \\
0
\end{array}\right]
\end{aligned}
$$

\section{4. モデルの制御系設計への応用}

ここでは，導出した線形モデルと低次元モデルを車両運 動制御系の解析に適用する．急操舵によってヨーレートが 過大になることを防ぐことを目的に，ヨーレート㹸制御 量とし，目標ヨーレートに対する状態フィードバックによ るサーボ系（Fig. 10）を構成する，ただし，Cは状態変数 ベクトルxからヨーレート $\gamma$ を出力する出力方程式の係数行 列である. 式(8)に示すように, 反力トルク $\Delta T_{r e}$ の比例係数 $K_{r e}$ は，トーションバーのねじれ角度 $\theta_{s p}$ の符号により異な

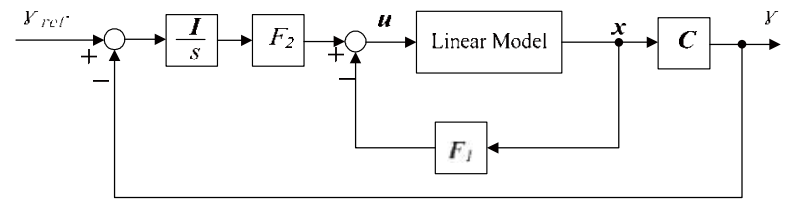

Fig. 10 Servo system based on linear model

るため, 比例係数 $K_{r e}$ が正負のそれぞれの場合について, 極配置法に従ってゲイン $F_{1}, F_{2}$ を計算した.

\subsection{8 次線形モデルによる制御系の設計}

はじめに, 式(22)の8次線形モデルをもとに, ヨーレート サーボ制御系を設計し，ステップ応答をFig. 11に示す. シ ミュレーションは, ハンドルトルク $T_{h}$ を時刻0sで 0 から 3 Nmにステップ状に変化させた場合を示す，その際の目標 ヨーレートは $0.1 \mathrm{rad} / \mathrm{s}=5.7 \mathrm{deg} / \mathrm{s} と し$, 車速は $90 \mathrm{~km} / \mathrm{h}$ 保
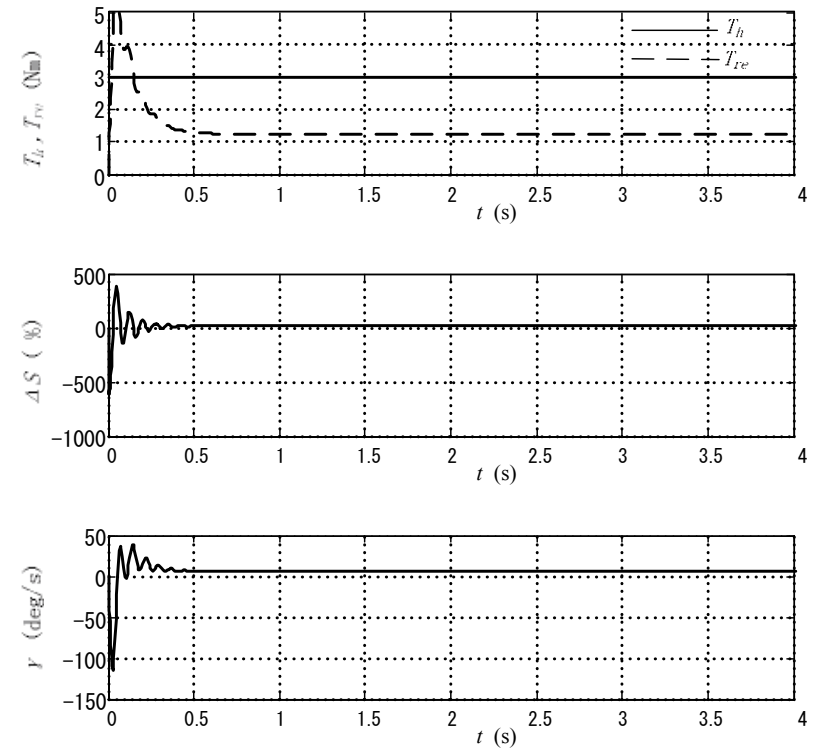

Fig. 11 Performance of controller based on 8th order linear model
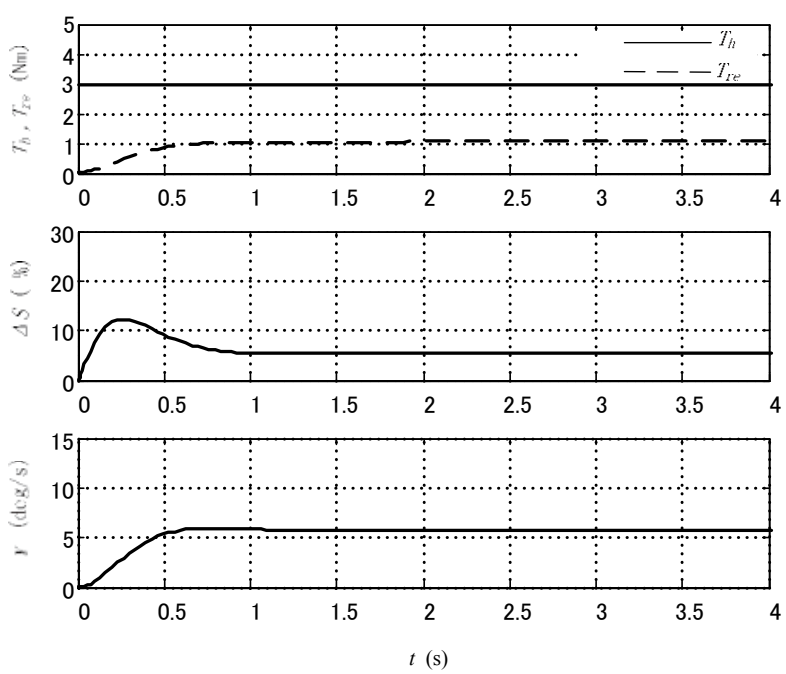

Fig. 12 Performance of controller designed on 3rd order linear model

持するものとした． ハンドルトルク $T_{h}$ のステップ入力が加 わると, ハンドルが回転し始め, ロータリバルブの角度が 増加し, 反力トルク $T_{r e}$ も急激に増加してヨーレート悐いっ たん減少する.ヨーレート骠值に戻すように反力ト ルク $T_{r e}$ が減少し, 定常状態ではヨーレート $\gamma$ は目標值に収 束する. しかし, 制御対象の次数が 8 次と高次であるため, 望ましい極配置の設定が容易ではなく, 制御入力が過大と なり，応答が振動的になった．また８次モデルの状態 フィードバックのために 8 個の状態変数を検出すること は現実的ではない，という課題がある.

\subsection{3次線形モデルによる制御系の設計}

3 次の低次元モデルをノミナルモデルとして，ヨーレー トサーボ制御系を求めた。計算したゲインを 3 次モデルに 適用したシミュレーション結果をFig. 12に示す. ヨーレー トyの応答速度はFig. 11と比べてやや遅くなったが, 振動 

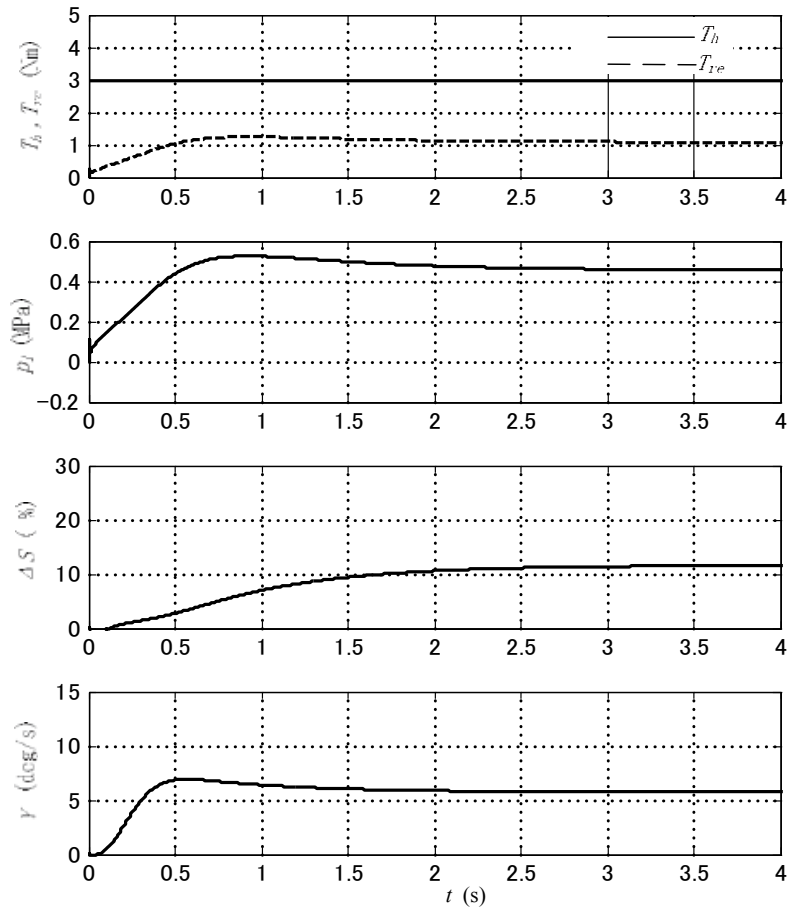

Fig. 13 Performance of 3rd-order-based controller with nonlinear model

が抑制され，滑らかになった。

\section{3 非線形モデルによる検証}

3 次低次元モデルをもとに計算したゲインの制御系を, IPSと車両モデルを統合した非線形統合モデルに適用して サーボ系を構成した場合のシミュレーションを行った．計 算結果をFig. 13に示す.

強い非線形性とパラメータ変動にもかかわらず, ヨー レートの応答には振動が現れず，目標ヨーレートに追従す ることが分かった．制御入力としての滑り率の差 $\Delta S$ S Fig. 12の結果より鈍くなった，その原因は，非線形統合モデル では $3 \mathrm{Nm}$ のハンドルトルクに対する応答は 3 次モデルの 場合より速いので, 滑り率の差は穏やかでも, ヨーレート がより速く目標値に追従できるためと考えられる.

\section{5. 結言}

油圧パワーステアリングを搭載する大型商用車の運動 制御系設計のために，油圧式パワーステアリングと車両の 統合モデルを構築した． 統合モデルのシミュレーション結 果を実車による実験結果と比べてその有効性を確認した.

統合モデルの線形近似モデルをもとに，操舵反力と左右 制動力配分を利用したヨーレートのサーボ制御系の設計 手法について, 油圧操舵系の動特性を考慮しながら検討し た、制御対象である非線形統合モデルを線形近似し，さら に低次元化する手法は，制御系の基本的な構造と制御ゲイ ンを求める理論的な根拠を示すことができる点で重要で ある．本研究の場合は，3次の低次元モデルで設計した制 御系を非線形統合モデルに適用し，良好な制御特性が得ら
れることを示した.

\section{参 考 文 献}

1 ) C. B. Winkler, D. F. Blower, R. D. Ervin, etc : Rollover of Heavy Commercial Vehicles, SAE Research Report (2000)

2 ）カヤバ工業株式会社：自動車の操舵系と操安性, 山 海堂, 187（1996）

3 ）小嶋英一, 西尾吉史, 王朝久：自動車用油圧パワー ステアリングシステムに発生する自励振動“ジャ ダー”に関する研究, 日本フルードパワーシステム 学会論文集，36-2，31/38（2005）

4 ) Pfeffer, Peter E., Harrer, Manfred, Johnston, D. Nigel, etc : Modelling of a hydraulic steering system, FISITA2006, Paper No. F2006V164（2006）

5 ) Baharom, Masri B, Hussain, Khalid, Day, Andrew $\mathrm{J}$ : Mathematical modelling of a cornering vehicle fitted with hydraulic power-assited-steering, FISITA 2006, Paper No. F2006V019 (2006)

6 ) 小野英一 : Estimation and Control of Vehicle Dynamics for Active Safety, 豊田中央研究所R\&DL ビュー, 40-4, 1/6 (2005)

7 ) 福井勝彦, 高橋俊道 : Study of the Performance of a Driver-vehicle System for Changing the Steering Characteristics of a Vehicle, 豊田中央研究所R\&D レビュー, 40-4，20/25（2005）

8 ) Y.Zeyada, D. Karnopp, M.El-Arabi, etc : A combined active-steering differential-braking yaw rate control strategy for emergency maneuvers, SAE Paper no. 980230

9 ) K.R. Buckholtz : Use of Fuzzy Logic in Wheel Slip Assignment-Part I : Yaw Rate Control, SAE Paper no. $2002-01-1220$

10）高 炳釗, 眞田一志, 降幡健一：油圧パワーステア リングのモデリングに関する研究, 平成18年春季フ ルードパワーシステム講演会講演論文集， 64/66 (2006)

11）高 炳釗, 眞田一志, 降幡健一：油圧パワーステア リングのモデリングに関する研究, 日本機械学会 2006年度年次大会講演論文集(2)，305/306（2006）

12）高 炳釗, 眞田一志, 降幡健一：油圧パワーステア リング式大型商用車のヨーレート制御に関する研究, 平成19年春季フルードパワーシステム講演会講演論 文集，97/99（2007）

13）真田一志, 北川能 : 油圧系のモデル化誤差を考虑し た自動変速機における回転数の 2 自由度制御の研究, 計測自動制御学会論文集，32-1，106/113（1996）

14）安部正人：自動車の運動と制御, 山海堂, 56 , 
(2003)

15）永井 正夫 : 追従性 - 安定性の基礎理論, 自動車技 術, 49-12, 41/47 (1995)
16）毛利 宏, 久保田正博, 堀口奈美: 過渡的な操舵力 アシスト特性が車両運動に及ぼす影響, 自動車技術 会論文集，37-1，155/160（2006） 